\title{
Effects of abomasal infusion of flaxseed (Linum usitatissimum) oil on microbial $\beta$-glucuronidase activity and concentration of the mammalian lignan enterolactone in ruminal fluid, plasma, urine and milk of dairy cows
}

\author{
Cristiano Côrtes ${ }^{1,2}$, Daniele da Silva-Kazama ${ }^{3,4}$, Ricardo Kazama ${ }^{3,4}$, Chaouki Benchaar ${ }^{1}$, \\ Geraldo dos Santos ${ }^{3}$, Lucia M. Zeoula ${ }^{3}$, N. Gagnon ${ }^{1}$ and Hélène V. Petit ${ }^{1 *}$ \\ ${ }^{1}$ Dairy and Swine Research and Development Centre, Agriculture and Agri-Food Canada, Stn Lennoxville, Sherbrooke, \\ Canada, QC J1M $1 Z 3$ \\ ${ }^{2}$ Département de Productions Animales, Unité de Recherche Systèmes d'Élevage, École Supérieure d'Agriculture d'Angers, \\ Angers 49007, France \\ ${ }^{3}$ Departamento de Zootecnia, Universidade Estadual de Maringa, Maringa, PR, Brazil \\ ${ }^{4}$ Departamento de Zootecnia e Desenvolvimento Rural, Universidade Federal de Santa Catarina, Florianópolis, SC, Brazil \\ (Submitted 5 December 2011 - Final revision received 15 March 2012 - Accepted 16 March 2012 - First published online 1 May 2012)
}

\section{Abstract}

Ruminal microbiota plays an important role in the conversion of plant lignans into mammalian lignans. The main mammalian lignan present in the milk of dairy cows fed flax products is enterolactone (EL). The objectives of the present study were to investigate the effects of abomasal infusion of flax oil on the metabolism of flax lignans and concentrations of EL in biological fluids of dairy cows. A total of six rumen-cannulated dairy cows were assigned within a $2 \times 3$ factorial arrangement of six treatments utilising flax hulls ( 0 and $15.9 \%$ of DM) and abomasal infusion of flax oil $(0,250$ and $500 \mathrm{~g} / \mathrm{d})$. There were six periods of $21 \mathrm{~d}$ each. Samples were collected during the last $7 \mathrm{~d}$ of each period and subjected to chemical analysis. Flax hull supplementation increased concentrations of EL in ruminal fluid, plasma, urine and milk, while flax oil infusion had no effect. Post-feeding, $\beta$-glucuronidase activity in the ruminal fluid of cows infused with $250 \mathrm{~g}$ flax oil was significantly lower for cows fed hulls than for those fed the control diet. The present study demonstrated that the presence of a rich source of $n-3$ fatty acids such as flax oil in the small intestine does not interfere with the absorption of the mammalian lignan EL and that lower ruminal $\beta$-glucuronidase activity had no effect on the conversion of flax lignans into EL in the rumen of dairy cows.

\section{Key words: Lignan: Enterolactone: $\beta$-Glucuronidase activity: Flaxseed}

The high level of $\alpha$-linolenic acid in flaxseed (Linum usitatissimum) makes it a good source of $n-3$ PUFA from plant origin for humans. Dietary addition of flaxseed increases the $n-3: n-6$ fatty acid ratio in food, and improvement of the ratio has been recognised as potentially beneficial to human health ${ }^{(1)}$. Moreover, flaxseed is the richest source of plant lignans which possess antitumour ${ }^{(2)}$, antioxidant ${ }^{(3)}$, antithrombic, weakly oestrogenic and anti-oestrogenic ${ }^{(3,4)}$ and anti-atherogenic effects $^{(5)}$. Plant lignans are polyphenolic compounds concentrated in the outer fibre-containing layers and the lignan secoisolariciresinol diglucoside (SDG) represents over $95 \%$ of the total lignans in flaxseed ${ }^{(6)}$.
The main site for the metabolism of flax lignans in nonruminant animals is the large intestine ${ }^{(7)}$. On the other hand, recent in vivo results have shown that the rumen is the main site for the metabolism of flax lignans in dairy cows ${ }^{(8)}$ Under the action of microflora, the plant lignan SDG is converted mainly into the two mammalian lignans enterodiol and enterolactone (EL), and enterodiol and EL are subsequently absorbed into the blood ${ }^{(9)}$. EL is the main lignan metabolite present in ruminal fluid ${ }^{(8)}$ and milk $^{(10)}$. In nonruminant animals, mammalian lignans are absorbed in the intestine and under the action of specific enzymes, they are conjugated as sulphate and glucuronide in the intestinal wall

Abbreviations: CON-0, no flax hull supplementation in the diet and no flax oil infused in the abomasum; CON-250, no flax hull supplementation and $250 \mathrm{~g}$ flax oil/d infused in the abomasum; CON-500, no flax hull supplementation and $500 \mathrm{~g}$ flax oil/d infused in the abomasum; EL, enterolactone; FHU-0, $15.9 \%$ flax hulls in the DM and no flax oil infused in the abomasum; FHU-250, 15.9\% flax hulls in the DM and 250 g flax oil/d infused in the abomasum; FHU-500, $15.9 \%$ flax hulls in the DM and $500 \mathrm{~g}$ flax oil/d infused in the abomasum; SDG, secoisolariciresinol diglucoside; VFA, volatile fatty acids. 
amount of oil used for infusion was prepared daily for each cow and was weighed into tared bottles. To perform abomasal infusions, an infusion line was inserted through the rumen cannula and the sulcus omasi into the abomasum as described by Gressley et $a l .{ }^{(18)}$. Placement of the infusion lines was monitored daily to ensure post-ruminal delivery. Oil was pumped into the abomasum by using peristaltic pumps (Masterflex L/S; Cole-Parmer Canada, Inc.).

\section{Sampling}

Feed intake and milk yield were measured daily. Milk samples were taken twice daily from day 16 to day 21, pooled on a $6 \mathrm{~d}$ basis proportionally to the corresponding milk yield, and frozen at $-20^{\circ} \mathrm{C}$ for EL analysis. On day 20, blood was withdrawn into $\mathrm{K}_{3}$ EDTA-vacutainer tubes (Becton Dickinson and Cie) from the jugular vein $6 \mathrm{~h}$ after the morning meal. Plasma samples were kept frozen at $-20^{\circ} \mathrm{C}$ until EL analysis. On day 21, a sample of urine was taken $2 \mathrm{~h}$ after the morning meal by hand stimulation of the perineal region and kept frozen at $-20^{\circ} \mathrm{C}$ for EL analysis. Also, ruminal contents were collected $0,2,4$ and $6 \mathrm{~h}$ after the morning meal from different locations within the rumen (the anterior dorsal, anterior ventral, medium ventral, posterior dorsal and posterior ventral locations) to obtain a representative sample. Ruminal $\mathrm{pH}$ was monitored immediately after sample collection with a portable $\mathrm{pH}$ meter (Oakton; Eutech Instruments Pte Limited). The ruminal contents were then strained through four layers of cheesecloth. A $350 \mathrm{ml}$ sample of strained ruminal fluid was mixed with rumen particles $(26 \mathrm{~g})$ and frozen at $-20^{\circ} \mathrm{C}$ until assay for $\beta$-glucuronidase activity. Then, one portion of filtered ruminal fluid was acidified to pH 2 with $50 \% \mathrm{H}_{2} \mathrm{SO}_{4}$ and frozen at $-20^{\circ} \mathrm{C}$ for the later determination of volatile fatty acids (VFA) and $\mathrm{NH}_{3}-\mathrm{N}$ concentrations. Concentrations of $\mathrm{NH}_{3}$ and VFA in ruminal fluid were analysed, respectively, with the indophenol blue method and a HPLC Waters Alliance 2695 system (Waters) fitted with a flame ionisation detector. Another portion of ruminal fluid was kept at $-20^{\circ} \mathrm{C}$ and freeze-dried for the analysis of EL. Ruminal samples for the three post-feeding times (2, 4 and $6 \mathrm{~h}$ ) were pooled within cow and period, as previously carried out by Gagnon et $a l{ }^{(8)}$, to obtain only one composite sample for EL analysis. Moreover, faecal grab samples $(250 \mathrm{~g})$ were collected directly from the rectum $2,4,6$ and $8 \mathrm{~h}$ post-feeding on the same day (day 21). Faecal $\mathrm{pH}$ was monitored immediately after sample collection. Faecal samples were pooled and kept frozen at $-20^{\circ} \mathrm{C}$ for further $\beta$-glucuronidase analysis.

\section{Lignan analysis and $\beta$-glucuronidase activity}

The analysis of SDG in the diets was performed according to the procedures described by Muir \& Westcott ${ }^{(19)}$. Lignans in ruminal fluid, plasma, urine and milk samples were hydrolysed, extracted and analysed as described by Gagnon et al. ${ }^{(8)}$. The determination of $\beta$-glucuronidase activity was based on a modified method of Jenab \& Thompson ${ }^{(13)}$. Briefly, faecal samples ( $5 \mathrm{~g}$ ) were homogenised with a Polytron (Kinematica AG) in a final volume of $20 \mathrm{ml}$ of cold $\mathrm{KH}_{2} \mathrm{PO}_{4}(\mathrm{pH}$ 6.8) for $15 \mathrm{~s}$, while ruminal samples were homogenised using a stomacher set at normal for 30 s. (A. J. Seward \& Company Limited). Samples were then filtered through two layers of cheesecloth, sonicated on ice (two bursts, $1 \mathrm{~min}$; Sonics and Materials, Inc.) and centrifuged at $10000 \mathrm{~g}$ for $15 \mathrm{~min}$ at $4^{\circ} \mathrm{C}$. The supernatant fraction was stored at $-80^{\circ} \mathrm{C}$ until the enzyme assay as described by Gagnon et $a l^{(8)}$.

\section{Statistical analysis}

All data were analysed using the MIXED procedure of SAS (2000; SAS Institute) according to a $6 \times 6$ Latin square with the following model:

$$
Y_{i j k}=\mu+a_{i}+\beta_{j}+\tau_{k}+e_{i j k},
$$

where $Y_{i j k}$ is the response variable; $\mu$ is the overall mean; $a_{i}$ is the random effect of cow $i ; \beta_{j}$ is the effect of period $j ; \tau_{k}$ is the global effect of treatment combination $k$; and $e_{i j k}$ is the residual error. Treatments were compared by contrasts in order to test the main effect of flax hulls and to test the polynomial effects (linear and quadratic) of oil in each level of flax hulls. Data on EL concentrations were log-transformed as previously done by Nesbitt et al. ${ }^{(20)}$, but the results in Table 3 present the adjusted mean values (with CI) backtransformed on the original scale of measurements. The model for specific $\beta$-glucuronidase activity and $\mathrm{pH}$ was augmented with time and time $\times$ treatment interaction for repeated measurements and values reported are adjusted means with their standard errors. Data on ruminal fermentation characteristics (VFA, $\mathrm{NH}_{3}-\mathrm{N}$ and $\mathrm{pH}$ ) were also analysed as repeated measurements and the compound symmetry was used as the covariance structure. The two-sided level of significance was set at $P<0 \cdot 05$, although probability values up to $P<0 \cdot 10$, suggesting a trend, are shown in the text. However, one cow was removed from the experiment due to udder damage that resulted in acute mastitis. As a result, data from treatments CON-0 and CON-500, which corresponded to the two last periods, were missing for the statistical analysis.

\section{Results}

\section{Oil supplementation and DM intake}

The actual amounts of oil infused in the abomasum averaged, respectively, 257 and $509 \mathrm{~g} / \mathrm{d}$ for cows that were planned to receive 250 and $500 \mathrm{~g} / \mathrm{d}$. There was a trend $(P=0.06)$ for an interaction between flax hulls and flax oil for DM intake expressed in $\mathrm{kg} / \mathrm{d}$, and the interaction was significant $(P=0.04)$ when DM intake was expressed as a percentage of body weight. There were linear $(P<0.0001)$ and quadratic $(P=0 \cdot 01)$ effects of abomasal infusion of oil on DM intake as a result of a decrease from 0 to $250 \mathrm{~g}$ flax oil while a plateau was reached when infusing 250 or $500 \mathrm{~g}$ flax oil (Table 2). However, the decrease in DM intake when no hulls were supplemented in the diet was greater than when the diets were supplemented with flax hulls. 
Table 2. Total input of DM (intake of DM + flax oil infused in the abomasum), intake of DM and ruminal fermentation characteristics of Holstein cows fed no flax hulls (CON) or supplemented with $15.9 \%$ flax hulls in the DM (FHU) and infused with three different amounts of flax oil in the abomasum $(0,250$ and $500 \mathrm{~g} / \mathrm{d})$

(Adjusted mean values with their standard errors)

\begin{tabular}{|c|c|c|c|c|c|c|c|c|c|c|}
\hline & \multicolumn{6}{|c|}{ Treatment } & \multirow[b]{4}{*}{ SEM } & \multirow{2}{*}{\multicolumn{3}{|c|}{$P$}} \\
\hline & \multicolumn{3}{|c|}{$\mathrm{CON}$} & \multicolumn{3}{|c|}{$\mathrm{FHU}$} & & & & \\
\hline & \multirow{2}{*}{$\begin{array}{c}0 \\
\text { Mean }\end{array}$} & \multirow{2}{*}{$\begin{array}{l}250 \\
\text { Mean }\end{array}$} & \multirow{2}{*}{$\begin{array}{c}500 \\
\text { Mean }\end{array}$} & \multirow{2}{*}{$\begin{array}{c}0 \\
\text { Mean }\end{array}$} & \multirow{2}{*}{$\begin{array}{c}250 \\
\text { Mean }\end{array}$} & \multirow{2}{*}{$\begin{array}{c}500 \\
\text { Mean }\end{array}$} & & \multicolumn{2}{|c|}{ Flaxseed } & \multirow[b]{2}{*}{ Interaction } \\
\hline & & & & & & & & Hulls & Oil & \\
\hline Total input of DM $(\mathrm{kg} / \mathrm{d})$ & $22 \cdot 8$ & $21 \cdot 1$ & $20 \cdot 7$ & $20 \cdot 6$ & $19 \cdot 7$ & 19.9 & 0.62 & $<0.0001$ & 0.0002 & 0.07 \\
\hline Intake of DM $(\mathrm{kg} / \mathrm{d})$ & $22 \cdot 8$ & $20 \cdot 8$ & $20 \cdot 2$ & $20 \cdot 6$ & $19 \cdot 4$ & $19 \cdot 4$ & 0.63 & $<0.0001$ & $<0.0001$ & 0.06 \\
\hline Intake of DM (\% body weight) & 3.5 & $3 \cdot 2$ & $3 \cdot 1$ & 3.2 & 3.0 & $3 \cdot 0$ & 0.09 & $<0.0001$ & $<0.0001$ & 0.04 \\
\hline $\mathrm{NH}_{3}-\mathrm{N}(\mathrm{mmol} / \mathrm{l})$ & 8.9 & $7 \cdot 6$ & $8 \cdot 7$ & $9 \cdot 7$ & $10 \cdot 6$ & $8 \cdot 7$ & 0.88 & 0.04 & 0.89 & 0.20 \\
\hline Volatile fatty acids ( $\mathrm{mmol} / \mathrm{l})$ & 108 & 104 & 104 & 108 & 106 & 104 & 3.69 & 0.77 & 0.54 & 0.77 \\
\hline \multicolumn{11}{|l|}{ Molar proportions $(\mathrm{mmol} / \mathrm{mol})$} \\
\hline Acetate & 645 & 648 & 631 & 598 & 607 & 603 & $7 \cdot 01$ & $<0.0001$ & 0.27 & 0.34 \\
\hline Propionate & 206 & 196 & 214 & 265 & 258 & 261 & 8.74 & $<0.0001$ & 0.38 & 0.60 \\
\hline Butyrate & 103 & 100 & 98.9 & 94.4 & 94.9 & $92 \cdot 0$ & $2 \cdot 51$ & 0.002 & 0.36 & 0.72 \\
\hline Isobutyrate & $6 \cdot 3$ & $7 \cdot 1$ & $7 \cdot 0$ & $6 \cdot 2$ & $6 \cdot 2$ & $6 \cdot 1$ & 0.22 & 0.001 & $0 \cdot 18$ & 0.19 \\
\hline Valerate & $10 \cdot 3$ & $10 \cdot 5$ & 11.4 & $10 \cdot 6$ & $10 \cdot 1$ & $10 \cdot 3$ & 0.44 & 0.27 & 0.37 & 0.32 \\
\hline Isovalerate & $18 \cdot 0$ & $18 \cdot 0$ & $16 \cdot 0$ & $14 \cdot 2$ & 13.5 & 14.5 & 0.90 & 0.0002 & 0.61 & $0 \cdot 19$ \\
\hline Lactate & $11 \cdot 0$ & $20 \cdot 7$ & $22 \cdot 8$ & $11 \cdot 3$ & $9 \cdot 8$ & $12 \cdot 9$ & $5 \cdot 89$ & $0 \cdot 14$ & 0.48 & 0.53 \\
\hline \multicolumn{11}{|l|}{ Molar ratios } \\
\hline Acetate:propionate & $3 \cdot 2$ & $3 \cdot 4$ & $3 \cdot 1$ & $2 \cdot 3$ & $2 \cdot 4$ & $2 \cdot 4$ & 0.13 & $<0.0001$ & 0.41 & 0.47 \\
\hline (Acetate + butyrate):propionate & 3.7 & 3.9 & 3.6 & $2 \cdot 7$ & $2 \cdot 8$ & $2 \cdot 7$ & 0.15 & $<0.0001$ & 0.42 & 0.50 \\
\hline
\end{tabular}

\section{Ruminal fermentation characteristics}

There were interactions between sampling time and flax hull supplementation for $\mathrm{NH}_{3}-\mathrm{N}$ concentration $(P=0 \cdot 001)$, molar proportions of acetate $(P=0.001)$, propionate $(P<0.0001)$, valerate $(P=0.009)$ and isovalerate $(P=0.005)$, the acetate: propionate ratio $(P<0.0001)$ and the (acetate + butyrate): propionate ratio $(P<0.0001)$ in the rumen. Moreover, the interaction tended $(P=0 \cdot 08)$ to be significant for molar proportions of butyrate and isobutyrate (data not shown). However, there was no interaction $(P>0 \cdot 10)$ between flax hull supplementation and flax oil infusion. $\mathrm{NH}_{3}-\mathrm{N}$ concentration in the rumen was higher $(P=0.04)$ for cows receiving flax hulls (Table 2). The concentration of total VFA in the rumen was not different among the treatments. Cows supplemented with flax hulls had a higher proportion of propionate and lower proportions of acetate, butyrate, isobutyrate and isovalerate in the rumen than those receiving the control diet (Table 2). Molar proportions of valerate and lactate in the rumen were similar for the CON and FHU treatments. The acetate:propionate ratio and the (acetate + butyrate): propionate ratio in the rumen were lower for cows fed the FHU diet compared with those fed the CON diet.

\section{Concentration of enterolactone in ruminal fluid, plasma, milk and urine}

There was no significant interaction $(P>0 \cdot 10)$ between hulls and oil for concentrations of EL in ruminal fluid, plasma, milk and urine. Concentrations of EL in ruminal fluid before feeding and post-feeding, plasma, urine and milk were higher $(P<0 \cdot 0001)$ for cows fed flax hulls than for those fed the control diets (Table 3). Flax oil infusion had no effect on the EL concentration of ruminal fluid, plasma, urine and milk.

\section{Activity of $\beta$-glucuronidase in ruminal fluid and faeces}

There was no interaction $(P=0.91)$ between time and treatment for $\beta$-glucuronidase activity in ruminal fluid, although there was an interaction $(P=0.03)$ for $\beta$-glucuronidase activity in the faeces (data not shown). The mean values for the $6 \mathrm{~h}$ faecal and ruminal sampling periods are presented in Table 4. On average, cows fed the FHU diet tended $(P=0.06)$ to have higher faecal $\beta$-glucuronidase activity than those fed the CON diet, and flax oil infusion had no effect. There was a significant interaction between hulls and oil for $\beta$-glucuronidase activity in ruminal fluid before and post-feeding $(P=0.01$ and 0.04 , respectively). There was a linear decrease $(P=0 \cdot 01)$ in ruminal $\beta$-glucuronidase activity before feeding with a higher amount of oil infused in the abomasum when cows were fed the CON diets, while there was a linear increase $(P=0.02)$ when cows were fed the FHU diets. Similarly, post-feeding, $\beta$-glucuronidase activity in ruminal fluid decreased linearly $(P=0 \cdot 04)$ with increased abomasal infusion of oil for cows fed the CON diets, while the activity only tended $(P=0 \cdot 09)$ to increase for cows fed the FHU diets.

\section{Ruminal fluid $\mathrm{pH}$}

There was no significant interaction $(P=0.43)$ between time and treatment for ruminal fluid $\mathrm{pH}$. Ruminal $\mathrm{pH}$ of cows fed flax hulls was lower $(P<0.01)$ than that of cows fed the control diets, and abomasal infusion of flax oil had no effect.

\section{Faecal pH}

There was an interaction between sampling time and supplementation with flax hulls $(P=0.04)$ and between sampling time and oil $(P=0.09)$ for faecal $\mathrm{pH}$. Faecal $\mathrm{pH}$ was higher $2 \mathrm{~h}$ 
Table 3. Concentration of enterolactone $(\mu \mathrm{mol} / \mathrm{l})$ in biological fluids of Holstein cows fed no flax hulls (CON) or supplemented with $15.9 \%$ flax hulls in the DM (FHU) and infused with three different amounts of flax oil in the abomasum $(0,250 \text { and } 500 \mathrm{~g} / \mathrm{d})^{\star}$

(Adjusted mean values and $95 \%$ confidence intervals on the original scale of measurement)

\begin{tabular}{|c|c|c|c|c|c|c|c|c|c|}
\hline & \multicolumn{6}{|c|}{ Treatment } & \multicolumn{3}{|c|}{$P$} \\
\hline & \multicolumn{3}{|c|}{ CON } & \multicolumn{3}{|c|}{ FHU } & \multicolumn{2}{|c|}{ Flaxseed } & \multirow[b]{2}{*}{ Interaction } \\
\hline & 0 & 250 & 500 & 0 & 250 & 500 & Hulls & Oil & \\
\hline \multicolumn{10}{|l|}{ Ruminal fluid } \\
\hline $\begin{array}{l}\text { Mean } \\
95 \% \mathrm{Cl} \\
\text { Pool }(2,4,6 \mathrm{~h})\end{array}$ & $\begin{array}{c}4.43 \\
2 \cdot 52,6 \cdot 06\end{array}$ & $\begin{array}{c}5 \cdot 15 \\
3 \cdot 20,7 \cdot 18\end{array}$ & $\begin{array}{c}4.43 \\
2 \cdot 89,6 \cdot 49\end{array}$ & $\begin{array}{c}20 \cdot 4 \\
11 \cdot 4,29 \cdot 4\end{array}$ & $\begin{array}{c}11 \cdot 4 \\
8 \cdot 72,14 \cdot 14\end{array}$ & $\begin{array}{c}15 \cdot 3 \\
8 \cdot 66,21 \cdot 6\end{array}$ & $<0.0001$ & 0.20 & 0.12 \\
\hline $\begin{array}{l}\text { Mean } \\
95 \% \mathrm{Cl}\end{array}$ & $\begin{array}{c}6 \cdot 87 \\
5 \cdot 16,8 \cdot 05\end{array}$ & $\begin{array}{c}7.37 \\
5.95,9.02\end{array}$ & $\begin{array}{c}7 \cdot 24 \\
5.97,8.52\end{array}$ & $\begin{array}{c}20 \cdot 7 \\
15 \cdot 4,25 \cdot 3\end{array}$ & $\begin{array}{c}19 \cdot 5 \\
13 \cdot 0,26 \cdot 6\end{array}$ & $\begin{array}{c}15 \cdot 8 \\
12 \cdot 2,19 \cdot 5\end{array}$ & $<0.0001$ & 0.39 & 0.32 \\
\hline \multicolumn{10}{|l|}{ Plasma } \\
\hline $\begin{array}{l}\text { Mean } \\
95 \% \mathrm{Cl}\end{array}$ & $\begin{array}{c}0.47 \\
0.40,0.65\end{array}$ & $\begin{array}{c}0.48 \\
0.38,0.59\end{array}$ & $\begin{array}{c}0.47 \\
0.41,0.56\end{array}$ & $\begin{array}{c}1 \cdot 79 \\
1 \cdot 28,2 \cdot 10\end{array}$ & $\begin{array}{c}1.40 \\
1.06,1.78\end{array}$ & $\begin{array}{c}1 \cdot 63 \\
0.56,2 \cdot 71\end{array}$ & $<0.0001$ & 0.75 & 0.74 \\
\hline \multicolumn{10}{|l|}{ Urine } \\
\hline $\begin{array}{l}\text { Mean } \\
95 \% \mathrm{Cl}\end{array}$ & $\begin{array}{c}40 \cdot 6 \\
26 \cdot 9,69 \cdot 4\end{array}$ & $\begin{array}{c}37.4 \\
15 \cdot 1,41 \cdot 8\end{array}$ & $\begin{array}{c}60 \cdot 0 \\
33 \cdot 4,61 \cdot 5\end{array}$ & $\begin{array}{c}294 \\
258,344\end{array}$ & $\begin{array}{c}335 \\
237,441\end{array}$ & $\begin{array}{c}235 \\
98 \cdot 5,377\end{array}$ & $<0.0001$ & 0.59 & 0.28 \\
\hline \multicolumn{10}{|l|}{ Milk } \\
\hline $\begin{array}{l}\text { Mean } \\
95 \% \mathrm{Cl}\end{array}$ & $\begin{array}{c}0.05 \\
0.02,0.08\end{array}$ & $\begin{array}{c}0.07 \\
0.03,0.06\end{array}$ & $\begin{array}{c}0.07 \\
0.01,0.12\end{array}$ & $\begin{array}{c}0.39 \\
0.17,0.63\end{array}$ & $\begin{array}{c}0.35 \\
0.15,0.58\end{array}$ & $\begin{array}{c}0.33 \\
0.22,0.46\end{array}$ & $<0.0001$ & 0.89 & 0.69 \\
\hline
\end{tabular}

* Data on enterolactone concentrations were log-transformed for statistical analysis.

post-feeding for cows fed flax hulls than for those fed the control diets (Fig. 1(a)), and faecal pH decreased linearly from 2 to $4 \mathrm{~h}$ post-feeding with a greater amount of oil infused in the abomasum of cows (Fig. 1(b)). However, there was no linear or quadratic effect of oil on the average value of faecal $\mathrm{pH}$ when cows were fed the CON or FHU diets.

\section{Discussion}

In human subjects, several studies have reported a positive relationship between the intake of flax lignans and the excretion of mammalian lignans in the urine and blood. In ruminants, our recent in vivo results ${ }^{(8)}$ have shown that the ruminal microbiome plays an important role in the metabolism of flax lignans as shown by higher concentrations of EL in the urine, plasma and milk of cows supplemented with flax hulls in the rumen when compared with cows administered with flax hulls in the abomasum. Other feed ingredients such as forages and cereals also contain lignans ${ }^{(21,22)}$, which may lead to the production of EL and explain the presence of EL in the ruminal fluid of dairy cows fed no flax hulls. To our knowledge, this is the first in vivo study investigating the effect of rumen bypass of PUFA on the metabolism and absorption of the mammalian lignan EL and its concentration in physiological fluids of dairy cows.

The highest DM intake observed for cows fed the CON-0 diet may be the result of a lower intake of fat compared with those fed the other five diets. Abomasal infusion of unsaturated long-chain fatty acids has been previously shown to decrease the DM intake of dairy cows ${ }^{(23,24)}$. According to Benson et $a l .{ }^{(23)}$, the suppressive effects of unsaturated longchain fatty acids may be mediated by the release of gut peptides, in particular glucagon-like peptide 1 , in response to increased quantities of unsaturated fatty acids reaching the proximal small intestine. The absence of flax hull supplementation resulted in a lower consumption of plant lignans and intakes of SDG averaged, respectively, 2·28, 2·08, 2·02, 47·38, 44.62 and $44.62 \mathrm{~g} / \mathrm{d}$ for cows fed the CON-0, CON-250, CON-500, FH-0, FHU-250 and FHU-500 diets. As previous results have shown that the rumen is the main site for the conversion of plant lignans into mammalian lignans ${ }^{(8)}$, greater intake of plant SDG for cows fed the flax hull-based diets

Table 4. Activity of $\beta$-glucuronidase (nmol phenolphthalein/min per mg protein) in the faeces and ruminal fluid of Holstein cows fed no flax hulls (CON) or supplemented with $15.9 \%$ flax hulls in the DM (FHU) and infused with three different amounts of flax oil in the abomasum $(0,250$ and $500 \mathrm{~g} / \mathrm{d})$

(Adjusted mean values with their standard errors)

\begin{tabular}{|c|c|c|c|c|c|c|c|c|c|c|}
\hline & \multicolumn{7}{|c|}{ Treatment } & \multirow{2}{*}{\multicolumn{3}{|c|}{$P$}} \\
\hline & \multicolumn{3}{|c|}{ CON } & \multicolumn{3}{|c|}{$\mathrm{FHU}$} & \multirow[b]{3}{*}{ SEM } & & & \\
\hline & \multirow{2}{*}{$\begin{array}{c}0 \\
\text { Mean }\end{array}$} & \multirow{2}{*}{$\begin{array}{c}250 \\
\text { Mean }\end{array}$} & \multirow{2}{*}{$\begin{array}{c}500 \\
\text { Mean }\end{array}$} & \multirow{2}{*}{$\begin{array}{c}0 \\
\text { Mean }\end{array}$} & \multirow{2}{*}{$\begin{array}{c}250 \\
\text { Mean }\end{array}$} & \multirow{2}{*}{$\begin{array}{c}500 \\
\text { Mean }\end{array}$} & & \multicolumn{2}{|c|}{ Flaxseed } & \multirow[b]{2}{*}{ Interaction } \\
\hline & & & & & & & & Hulls & Oil & \\
\hline Faeces & $10 \cdot 1$ & $12 \cdot 1$ & $12 \cdot 9$ & $13 \cdot 5$ & $14 \cdot 2$ & $14 \cdot 5$ & $1 \cdot 73$ & 0.06 & 0.43 & 0.82 \\
\hline Ruminal fluid (0 h) & $1 \cdot 36$ & $1 \cdot 25$ & 0.96 & 0.89 & 1.04 & $1 \cdot 22$ & 0.14 & $0 \cdot 10$ & 0.88 & 0.01 \\
\hline Ruminal fluid pool $(2,4,6 \mathrm{~h})$ & 1.79 & $1 \cdot 71$ & 1.44 & 1.01 & $1 \cdot 16$ & $1 \cdot 31$ & 0.14 & 0.0001 & 0.86 & 0.04 \\
\hline
\end{tabular}



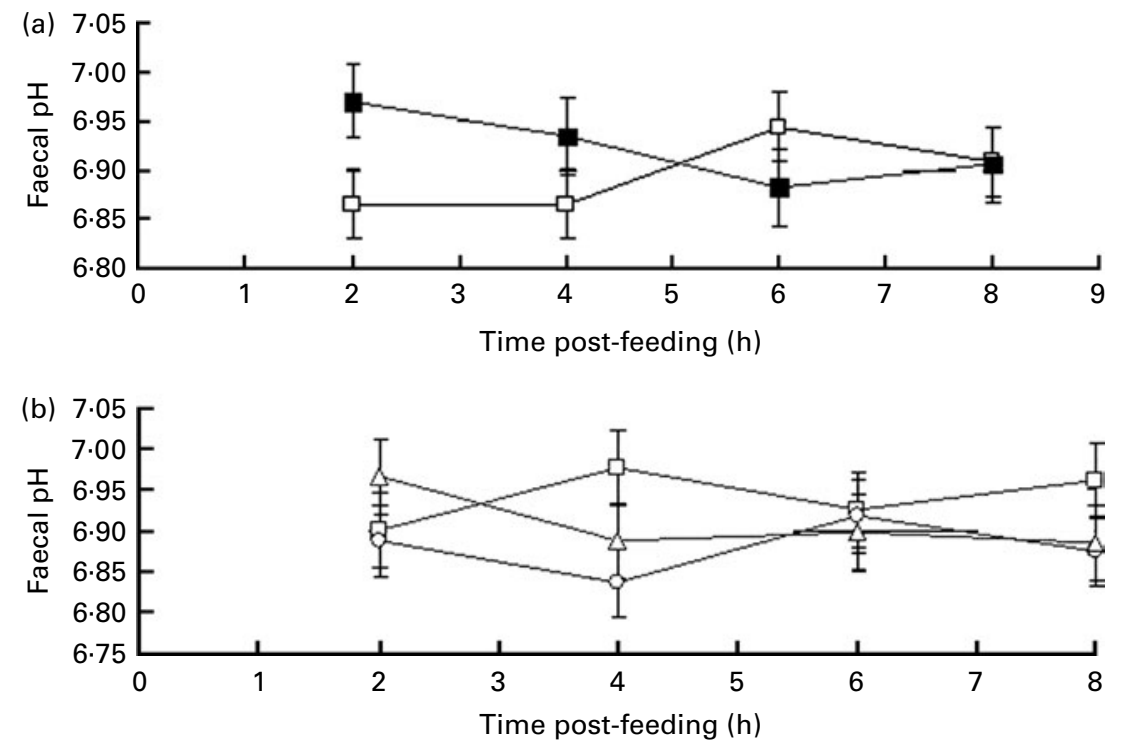

Fig. 1. Post-feeding $\mathrm{pH}$ in the faeces (a) of dairy cows supplemented with flax hulls and flax oil. For (a), the treatments were as follows: (1) no flax hull supplementation in the diet (- - , CON); (2) $15.9 \%$ flax hulls in the DM (- - , FHU). For (b), the treatments were as follows: (1) no flax oil infused in the abomasum ( $\square$ - 0 ); (2) $250 \mathrm{~g}$ flax oil/d infused in the abomasum (-O-, 250); (3) $500 \mathrm{~g}$ flax oil/d infused in the abomasum ( $-\triangle, 500)$. Values are adjusted mean values with their standard errors represented by vertical bars. The effect of flax hull supplementation on ruminal $\mathrm{pH}$ was significant $(P<0.01)$ and there was an interaction between time and oil $(P=0.04)$ and time and hull $(P=0.08)$ for faecal $\mathrm{pH}$.

will probably increase the concentration of EL in the rumen, as observed in the present experiment. Similarly, Zhou et al. ${ }^{(25)}$ reported increased ruminal EL concentrations and decreased $\mathrm{pH}$ when the pure lignan SDG was infused in the rumen of goats. In the present experiment, ruminal fluid $\mathrm{pH}$ also decreased with flax hull supplementation, as previously reported by Gagnon et al. ${ }^{(8)}$. Flax hulls are a rich source of fermentable carbohydrates, which may contribute to lower $\mathrm{pH}$ and increase the proportion of propionate in the rumen of cows supplemented with flax hulls due to greater availability of carbohydrates in the rumen ${ }^{(26)}$. Moreover, diets based on flax hulls may contribute to increasing the concentration of $\mathrm{NH}_{3} \mathrm{~N}$ in the rumen, as previously reported for beef cattle fed increasing levels of whole flaxseed ${ }^{(27)}$ as a result of high crude protein degradability $(67 \cdot 3 \%)$ of flaxseed in the rumen $^{(28)}$.

Cows fed flax hulls (diets FHU-0, FHU-250 and FHU-500) had concentrations of EL that were on average (mean of the three flax hull treatments) $3.4,6.7$ and 5.8 times higher in the plasma, urine, and milk, respectively. This agrees with the results of Petit \& Gagnon ${ }^{(29)}$ who reported a linear increase in milk EL concentration when dairy cows were fed from 0 to $15 \%$ flaxseed meal in the diet. Moreover, other results $^{(8)}$ have shown that administration of $1800 \mathrm{~g}$ flax hulls/d in the rumen compared with the abomasum significantly increases the concentrations of EL in the plasma, urine and milk.

In the present study, SDG metabolism was not affected by the presence of PUFA in the small intestine, as indicated by similar concentrations of EL in the plasma, urine and milk of cows infused or not with flax oil in the abomasum. A study has shown that a high intake of fat was significantly associated with lower concentrations of EL in the plasma of women ${ }^{(30)}$.
In rats, fat has been shown to reduce the absorption and recirculation of lignans ${ }^{(31)}$, which may suggest that fat reduces the capacity of the colonic microflora to convert plant lignans into mammalian lignans in single-stomached animals. Therefore, it seems likely that the main site of conversion of the plant lignan SDG into the mammalian lignan EL is the rumen, as previously reported by Gagnon et $a l^{(8)}$. Moreover, the results of the present study may indicate that the presence of PUFA in the small intestine does not interfere with the absorption of the mammalian lignan EL in ruminant animals. However, further investigations on the metabolism of mammalian lignans along the gastrointestinal tract of cattle are required to confirm the site of absorption of EL to improve the understanding of its metabolic pathway in dairy cows, in order to enable targeted manipulation of its quantity in milk.

Although Jenab \& Thompson ${ }^{(13)}$ observed a positive correlation between SDG dietary concentration and microbial $\beta$-glucuronidase activity with colonic microbiota from rats, the opposite was observed in the present experiment for $\beta$-glucuronidase activity in the ruminal fluid. Indeed, supplementation with flax hulls resulted in lower post-feeding microbial $\beta$-glucuronidase activity in cows fed the 0 and 250 oil treatments compared with cows fed the same treatments but unsupplemented with flax oil. In goats, Zhou et al. ${ }^{(25)}$ suggested that SDG supplementation stimulates the growth of Ruminococcus gnavus, which plays a role in glucuronidase activity of the rumen. However, as flax hulls are rich in fat and $n$ - 3 fatty acids, this may indicate a negative effect of fatty acids on $\beta$-glucuronidase activity in the rumen.

In the present experiment, supplementation with flax hulls tended to increase faecal $\beta$-glucuronidase activity, which agrees with the positive correlation between SDG dietary concentration and microbial $\beta$-glucuronidase activity with 
colonic microbiota from rats ${ }^{(13)}$. This result suggests that microbial $\beta$-glucuronidase activity in the colon may contribute to the absorption of mammalian lignans in ruminants as previously reported in human subjects ${ }^{(13)}$. Gagnon et al. ${ }^{(8)}$ have reported that flax hulls introduced directly in the rumen had no effect on faecal $\beta$-glucuronidase activity. Discrepancies between experiments may be explained by the site of supplementation as hulls were administered in the rumen in the experiment of Gagnon et al. ${ }^{(8)}$ while hulls were added to the diets in the present experiment. Intake of hulls by cows may result in greater breakdown of seed coat than administration in the rumen due to chewing, which in turn may result in a greater release of plant lignans from seeds.

Lower faecal $\mathrm{pH}$ for cows not supplemented with flax hulls may be the result of greater amounts of starch reaching the colon and being fermented by intestinal microflora, which probably results from the production of short-chain VFA that lower colonic $\mathrm{pH}$ and serve as an energy source for the colonocytes ${ }^{(26)}$. Indeed, the control diets contained greater amounts of cereals than the FHU treatments (198v. 133 g/kg DM) and previous results have shown that fermentation of starch in the hindgut decreases faecal $\mathrm{pH}^{(32)}$.

A study has shown a decrease in the incidence of CVD with greater blood concentration of EL in human subjects ${ }^{(33)}$. Moreover, our recent results have demonstrated that antioxidants such as flax hulls tended $(P=0.09)$ to increase the activity of superoxide dismutase in the mammary gland ${ }^{(34)}$. Greater activity of superoxide dismutase, which is the first enzyme involved in the conversion of oxygen radicals to peroxides ${ }^{(35)}$, may then contribute to improve the health of the mammary gland and milk quality. Other results have shown ${ }^{(36)}$ in rat models that flax lignans up-regulate the expression of hepatic genes encoding for enzymes such as superoxide dismutase, catalase and glutathione peroxidase that are involved in defence mechanisms against oxidative stress. Altogether, these results have suggested beneficial effects of flax hulls on the health of human subjects and animals. However, further investigations are required to better understand the impact of increasing mammalian lignans in biological fluids on the productivity and health of dairy cows.

In conclusion, the presence of $n-3$ fatty acids such as flax oil in the small intestine does not interfere with the absorption of the mammalian lignan EL in ruminant animals. Moreover, the results suggest a potential role of colonic microbiota in the absorption of mammalian lignans, although further investigations on the metabolism of mammalian lignans along the gastrointestinal tract of cattle are required to better improve our knowledge on the metabolism of plant lignans in order to increase the concentration of the mammalian lignan EL in the milk of dairy cows.

\section{Acknowledgements}

The present study was funded by the Agriculture and Agri-Food Canada. The authors would like to express their gratitude to the staff of the Dairy and Swine Research and Development Centre for their contribution to the present study. We especially want to thank Véronique Roy, Liette
Veilleux and Sylvie Dallaire for their technical assistance and Steve Méthot for his help in the statistical analyses. R. K. and D. d. S.-K. were recipients of a studentship and G. d. S. and L. M. Z. were recipients of a fellowship from Conselho Nacional de Desenvolvimento Científico e Tecnológico and Fundação Araucária do Paraná. C. C. was a recipient of a fellowship from the National Science and Engineering Research Council of Canada. C. C. and H. V. P. drafted the manuscript. H. V. P. conceived and directed the study and C. C. coordinated the study. C. C. and R. K. were in charge of the infusions and of collecting the data from the animals. D. d. S.-K. and N. G. were in charge of performing the laboratory work. G. d. S. and L. M. Z. participated in the design of the study. C. B. contributed to the conception and design of the experiment and to the interpretation and discussion of the results. All authors were involved in revising the paper critically and approved the final version of the manuscript. H. V. P. supervised the work of R. K. and D. d. S.-K. in Canada. None of the authors had a personal or professional conflict of interest.

\section{References}

1. Wright TC, McBride BW \& Holub BJ (1998) Docosahexaenoic acid-enriched milk. World Rev Nutr Diet 83, 160-165.

2. Thompson LU, Seidl MM, Rickard SE, et al. (1996) Antitumorigenic effect of a mammalian lignan precursor from flaxseed. Nutr Cancer 26, 159-165.

3. Kitts DD, Yuan YV, Wijewickreme AN, et al. (1999) Antioxidant activity of the flaxseed lignan secoisolariciresinol diglycoside and its mammalian lignan metabolites enterodiol and enterolactone. Mol Cell Biochem 202, 91-100.

4. Martin ME, Haourigui M, Pelissero C, et al. (1996) Interactions between phytoestrogens and human sex steroid binding protein. Life Sci 58, 429-436.

5. Sano T, Oda E, Yamashita T, et al. (2003) Antithrombic and anti-atherogenic effects of partially defatted flaxseed meal using a laser-induced thrombosis test in apolipoprotein $\mathrm{E}$ and low-density lipoprotein receptor deficient mice. Blood Coagul Fibrinolysis 14, 707-712.

6. Thompson LU, Robb P, Serraino M, et al. (1991) Mammalian lignan production from various foods. Nutr Cancer $\mathbf{1 6}$ 43-52.

7. Setchell KDR, Lawson AM \& Mitchell FL (1980) Lignans in man and in animal species. Nature 287, 740-742.

8. Gagnon N, Côrtes C, Da Silva D, et al. (2009) Ruminal metabolism of flaxseed (Linum usitatissimum) lignans to the mammalian lignan enterolactone and its concentration in ruminal fluid, plasma, urine and milk of dairy cows. Br J Nutr 102, 1015-1023.

9. Borriello SP, Setchell KDR, Axelson M, et al. (1985) Production and metabolism of lignans by the human faecal flora. J Appl Bacteriol 58, 37-43.

10. Petit HV, Gagnon N, Priyadarshini SM, et al. (2009) Milk concentration of the mammalian lignan enterolactone milk production milk fatty acid profile and digestibility in dairy cows fed diets containing whole flaxseed or flaxseed meal. J Dairy Res 76, 257-264.

11. Barnes S, Sfakianos J, Coward L, et al. (1996) Soy isoflavonoids and cancer prevention: underlying biochemical and pharmacological issues. Adv Exp Med Biol 401, 87-100. 
12. Hoikkala AA, Schiavoni E \& Wahala K (2003) Analysis of phyto-oestrogens in biological matrices. Br J Nutr 89, Suppl. 1, S5-S18.

13. Jenab M \& Thompson LU (1996) The influence of flaxseed and lignans on colon carcinogenesis and $\beta$-glucuronidase activity. Carcinogenesis 17, 1343-1348.

14. Edmonson AJ, Lean IJ, Weaver LD, et al. (1989) A body condition scoring chart for Holstein for dairy cows. J Dairy Sci 72, 68-78.

15. NRC, (editor). (2001) National Research Council, Nutrient Requirements of Dairy Cattle, 7th rev. ed. Washington, DC: National Academy Press.

16. CCAC (Canadian Council on Animal Care) (1993) Guide to Care and Use of Experimental Animals. ED Offert, BM Cross and AA McWilliam (editors) Ottawa, ON: CCAC.

17. Côrtes C, da Silva-Kazama DC, Kazama R, et al. (2010) Milk composition, milk fatty acid profile, digestion, and ruminal fermentation in dairy cows fed whole flaxseed and calcium salts of flaxseed oil. J Dairy Sci 93, 3146-3157.

18. Gressley TF, Reynal SM, Colmenero JJO, et al. (2006) Development of a tool to insert abomasal infusion lines into dairy cows. J Dairy Sci 89, 3965-3967.

19. Muir AD \& Westcott ND (2000) Quantitation of the lignan secoisolariciresinol diglucoside in baked goods containing flax seed or flax meal. J Agric Food Chem 48, 4048-4052.

20. Nesbitt PD, Lam Y, Thompson LU (1999) Human metabolism of mammalian lignar precursors in raw and processed flaxseed. Am J Clin Nutr 69, 549-555.

21. Steinshamn H, Purup S, Thuen E, et al. (2008) Effects of clover-grass silages and concentrate supplementation on the content of phytoestrogens in dairy cow milk. J Dairy Sci 91, 2715-2725.

22. Peñalvo JL, Haajanen KM, Botting N, et al. (2005) Quantification of lignans in food using isotope dilution gas chromatography/mass spectrometry. J Agric Food Chem 53, 9342-9347.

23. Benson JA, Reynolds CK, Humphries DJ, et al. (2001) Effects of abomasal infusion of long-chain fatty acids on intake, feeding behavior and milk production in dairy cows. J Dairy Sci 84, 1182-1191.

24. Litherland NB, Thire S, Beaulieu AD, et al. (2005) Dry matter intake is decreased more by abomasal infusion of unsaturated free fatty acids than by unsaturated triglycerides. J Dairy Sci 88, 632-643.
25. Zhou W, Wang G, Han Z, et al. (2009) Metabolism of flaxseed lignans in the rumen and its impact on ruminal metabolism and flora. Anim Feed Sci Technol 150, 18-26.

26. Slavin JL (2000) Mechanisms for the impact of whole grain foods on cancer risk. J Am Coll Nutr 19, 300S-307S.

27. Scholljegerdes E \& Kronberg S (2008) Influence of level of supplemental whole flaxseed on forage intake and site and extent of digestion in beef heifers consuming native grass hay. J Anim Sci 86, 2310-2320.

28. Mustafa AF, Gonthier C \& Ouellet DR (2003) Effects of extrusion of flaxseed on ruminal and postruminal nutrient digestibilities. Arch Anim Nutr 57, 455-463.

29. Petit HV \& Gagnon N (2009) Milk concentrations of the mammalian lignans enterolactone and enterodiol milk production and whole tract digestibility of dairy cows fed diets containing different concentrations of flaxseed meal. Anim Feed Sci Technol 152, 103-111.

30. Johnsen NF, Hausner H, Olsen A, et al. (2004) Intake of whole grains and vegetables determines the plasma enterolactone concentration of Danish women. J Nutr 134, 2691-2697.

31. Bylund A, Zhang JX, Bergh A, et al. (2000) Rye bran and soy protein delay growth and increase apoptosis of human LNCaP prostate adenocarcinoma in nude mice. Prostate $\mathbf{4 2}$, 304-314.

32. Gressley TF, Hall MB \& Armentano LE (2011) Ruminant nutrition symposium: productivity, digestion, and health responses to hindgut acidosis in ruminants. J Anim Sci 89, 1120-1130.

33. Vanharanta M, Voutilainen S, Lakka TA, et al. (1999) Risk of acute coronary events according to serum concentrations of enterolactone: a prospective population-based case-control study. Lancet 354, 2112-2115.

34. Côrtes C, Palin MF, Gagnon N, et al. (2012) Mammary gene expression and activity of antioxidant enzymes and concentration of the mammalian lignan enterolactone in milk and plasma of dairy cows fed flax lignans and infused with flax oil in the abomasum. BrJ Nutr (epublication ahead of print version 3 January 2012).

35. Yu BP (1994) Cellular defenses against damage from reactive oxygen species. Physiol Rev 74, 139-162.

36. Rajesha J, Murthy KNC, Kumar MK, et al. (2006) Antioxidant potentials of flaxseed by in vivo model. J Agric Food Chem 54, 3794-3799. 